\title{
The Readiness of Islamic Banking in Indonesia to Implement Digital and Green Banking
}

\author{
Malik Cahyadin $^{1)}$, Tamat Sarmidi ${ }^{2}$, Elsa Adelia Nurrachma ${ }^{1)}$ \\ ${ }^{1)}$ Faculty of Economics and Business, Universitas Sebelas Maret \\ ${ }^{2}$ Faculty of Economics and Management, The National University of Malaysia \\ Corresponding Author: malikcahyadin@yahoo.com
}

Recieved: September 2018 | Revised: April 2019 | Accepted: July 2019

\begin{abstract}
This study aims to analyze: (a) the relationship between Islamic banking asset and financing, ICT index, and environmental quality index in Indonesia; and (b) the readiness level of Islamic banking in Indonesia to implement digital and green banking. The data used are asset growth, financing growth, IDI and IKLH. Period of data covers annually from 2010-2016. Methods of data analysis include descriptive statistics, correlation and Granger causality test. The results show that: (a) asset and financing of Islamic Banking have correlation/ causality with IDI and IKLH; and (b) the readiness level of digital banking is 3 while the readiness level of green banking is 1. Islamic banking in Indonesia has utilized ICT in asset management and financing. Meanwhile, Islamic banking has not been able to play an active role in controlling the environmental impact of financial transactions. The recommendation of this research is OJK should set periodization of digital and green banking implementation in Islamic banking supported by DSN-MUI statement. OJK could also establish the index of digital and green banking in Indonesia Islamic banking.
\end{abstract}

Keywords: readiness level, digital banking, green banking, Islamic bank JEL Classification: G21, O33, Q56

How to Cite: Cahyadin, M., Sarmidi, T., \& Nurrachma, E. (2019). The Readiness of Islamic Banking in Indonesia to Implement Digital and Green Banking. Jurnal Ekonomi Pembangunan: Kajian Masalah Ekonomi dan Pembangunan, 20(2). 176-192. doi:https://doi.org/10.23917/jep.v20i2.6757

DOI: https://doi.org/10.23917/jep.v20i2.6757

\section{Introduction}

Bank Indonesia (2008) identifies the obstacles to the development of Islamic banking in Indonesia including the development of non-significant business indicators and the acceleration of unimplemented Islamic banking market development. Meanwhile, OJK (2015) formulates one of the strategic issues of Islamic banking development in Indonesia, namely: the availability and readiness of information technology (ICT). To that end, OJK (2015) establishes the policy/terms of sharing and inter-operability of ICT of Islamic banking in Indonesia.

Vater, Cho, \& Sidebottom (2012) explained that the banking and consumer industries are being concentrated to maximize the utilization of ICT in financial transactions. Therefore, Kamra (2014) and Jaubert, Ullrich, Dela, Marcu, and Malbate (2014) recommend the omni channel approach as an integrated ICT in financial transactions. Thus, the banking industry including Islamic banking needs to design ICT development and utilization strategies in the process of digitizing Islamic financial transactions. ICT utilization in the form of internet banking in business actors in Indonesia in 2011 only reached 51.01\% (Ministry of Communications and Informatics RI, 2011).

According to DeLaCastro, et al (2014), there are several benefits of ICT in banking, namely: 
Jurnal Ekonomi Pembangunan: Kajian Masalah Ekonomi dan Pembangunan, 20 (2), 2019, 176-192

market expansion, consumer satisfaction and loyalty, business interrelation and longterm profitability. In addition, DeLaCastro, et al (2014) also identified seven strategies as elements of a digital strategy, namely: infrastructure strategy; data; content; business process; analytic, social and mobility; and user experience. Meanwhile, Lipton, Shrier, \& Pentland (2016) explain there are several considerations to achieve the success of digital banking, namely: customer focus; openness to innovation; the flexibility of innovation; organizational flexibility; long-term vision and short-term implementation; and digital culture inclusively. OJK (2016) has set a digital branch that can be a reference for the banking industry with several types, namely: outlets; cash office; and sub-branch offices. Implementation of digital branch in Indonesia is done in two phases, namely: digital branch phase and banking phase anywhere (OJK, 2016).

In addition to the application of digital banking, Islamic banking in Indonesia is also expected to have awareness and partiality towards the quality of the environment in determining the allocation of financing and financial transactions. This means that Islamic banks apply green banking. Jha and Bhome (2013) explains that green banking can be done by banking practices directed to online/ digital banking; allocation of financing that has a positive impact on the environment; saving energy usage; saving paper usage; credit card and green checking account. Garg (2015); Oyegunle and Weber (2015) added that the implementation of green banking is one of the considerations of a bank having concern for climate change/environmental, economic and social responsibility. Some examples of green banking activities are setting low interest rates (conventional banks) for disaster prone areas, designing and marketing environmentally friendly products/financial services, making environmental risk management in banking transaction management decisions (Chowdhury \& Dey, 2016).
According to Julia, Rahman, and Kassim (2016) green banking practices need to be established based on the principles of Islam. Examples of the implementation of green banking in Bangladesh include investment management, deposit management, housekeeping, human capital recruitment and development, corporate social responsibility, and promotion (Masukujjaman, Siwar, Mahmud, \& Alam, 2016). Sahoo, Singh, and Jain (2016) added that green banking can also be referred as ethical banking. This is clarified by Uddin (2016) that the sustainability and environmental protection associated with financial transactions is an important part of Islam. Nor (2016) offers an idea on Islamic social bank that can be adopted by Islamic banking both in funding and financing.

The studies on digital and green banking serve as the reference for this study to analyze the readiness of Islamic banking in Indonesia in the implementation of digital and green banking (see Chowdhury \& Dey, (2016); DeLaCastro et al., (2014); Otoritas Jasa Keuangan (2015); Jha \& Bhome, (2013); Lipton et al., (2016); OJK, (2016)). This readiness can be measured using the concept of technology readiness level (TRL) set by NASA (2017) in https://www.nasa.gov). There are nine levels of TRL starting from the basic principles of the technology being researched and reported (level 1) until the system is thoroughly tested/proven through successful operation (level 9).

There are two research problems cover in this research, namely: (a) how is the relationship between Islamic banking asset and financing, ICT index and environmental quality index in Indonesia?: and (b) how is the readiness level of Islamic banking in Indonesia in the implementation of digital and green banking?. Hence, this research examines the two objectives. The first objective is relationship between Islamic banking asset and financing, ICT index and environmental quality index in Indonesia. And the second objective is to identify the readiness level of implementation 
of digital and green banking. We use descriptive statistics, correlation and Granger causality test to enlighten the first objective. Meanwhile, the TRL from NASA (2017) is employed to identify the readiness level of digital and green banking implementation in Indonesian Islamic Banking.

\section{Method}

This study uses secondary data from 2010 to 2016. The data include growth of asset of Islamic Commercial Bank and Islamic Business Unit (GABUS), growth of asset of Islamic Rural Bank (GABPRS), growth of financing of Islamic Commercial Bank and Islamic Business Unit (GFBUS), growth of financing of Islamic Rural Bank (GFBPRS), ICT Development Index (IDI) of Indonesia, and Environmental Quality Index (IKLH) of Indonesia. The data were obtained from the Financial Services Authority (OJK) Indonesia, the Ministry of Environment and Forestry (KLHK) RI, and the International Telecommunication Union (ITU).

Research methods use descriptive statistics, correlation, Granger Causality Test, and TRL. Correlation method refers to Taylor (1990) while Granger Causality Test refers to White \& Pettenuzzo (2014). The analysis scheme in this study is as follows (Figure 1).

The process of testing the interrelationship between asset and financing of Islamic banking with IDI and IKLH is using correlation and Granger causality test. Both of these methods will explain how the interrelationship between the variables studied. The results of both methods will be used as a reference in determining readiness level of Islamic banking in the implementation of digital and green banking.

The determination of Islamic banking readiness level in the implementation of digital and green banking uses TRL criteria (see Appendix). It was set by authors that adapted from NASA (2017). The detail criteria of TRL can be accessed at the website https://www. nasa.gov/pdf/458490main_TRL_Definitions.pdf.

This research identifies that Islamic Banking in Indonesia tends to able to use and share the ICT utilization in financial transactions (see Table 1 and Table 4). Meanwhile, the power of Islamic banking to control environmental quality in the process of financial transaction needs to be improved (see Table 1, 3, and 4). The result of Table 1, 3, and 4 become consideration to identify the readiness level of digital (IDI) and environmental quality (IKLH) in Islamic banking industry in Indonesia. Thus, there are two steps that will be conducted in this research. The first step is examining the relationship of banking indicators, IDI and IKLH uses correlation and Granger causality test. Moreover, the second step is identifying the level of readiness of digital and green banking uses the relationship result (point 1) and TRL criteria.

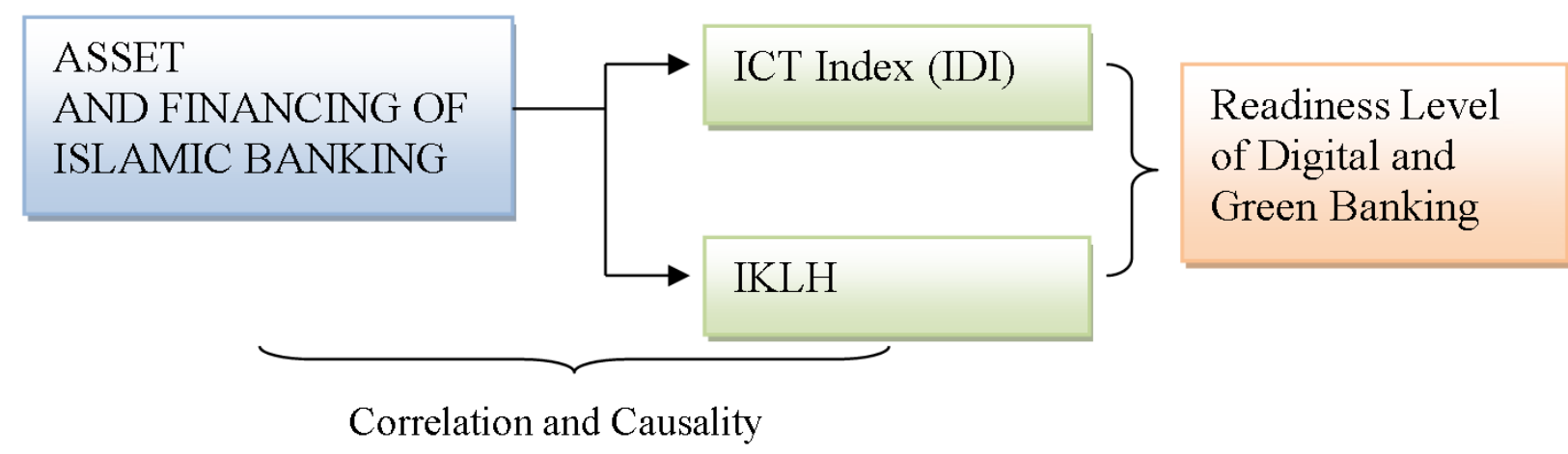

Figure 1. The Schematic of Research Analysis 
Jurnal Ekonomi Pembangunan: Kajian Masalah Ekonomi dan Pembangunan, 20 (2), 2019, 176-192

\section{Result and Discussion}

\subsection{Result}

The development of Islamic banking during 2010-2016 based on average asset growth (GABS) is $33.48 \%$ (Table 1). The maximum and minimum of Islamic banking asset growth (GABS) are $48.60 \%$ and $13.56 \%$, respectively. Meanwhile, the average asset growth of Islamic commercial bank and Islamic business unit (GABUS) was $33.69 \%$ (above GABS) and GABPRS (average asset growth of Islamic rural bank) was $26.55 \%$ (below GABS). This figure shows that Islamic banking can be developed in acceleration, especially Islamic commercial bank and Islamic business unit.

The maximum and minimum growth of financing of Islamic commercial bank and Islamic business unit (GFBUST) is $50.56 \%$ and $6.86 \%$ with average growth of $34.27 \%$ (above GABS). Meanwhile, the maximum and minimum growth of BPRS financing (GFBPRST) is $32.80 \%$ and $15.19 \%$ with average growth of $26.49 \%$ (below GABS). The development of financing is expected to be driven by keeping in mind the risk management of financing.

Islamic banking industry can promote the financial product and services in order to increase financing transaction progressively. We can refer to the value of asset and financing growth tend to lower than $60 \%$. It means that Islamic banking still need to encourage the growth of financing to the level of $100 \%$. Hence, Islamic banking is expected to contribute to the domestic market maximally.

The maximum and minimum value of ICT Development Index (IDI) is 3.83 and 3.10 points with an average value of 3.41 point. The IDI point scale is 1 - 10 points with three forming indicators, namely (ITU, 2011): (a) ICT Readiness (infrastructure, access); (B) ICT Use (intensity); and (c) ICT Capability (skills). This indicates that the development and utilization of ICT in Indonesia during 2010-2016 is sufficiently developed. In addition, Islamic banking in Indonesia is expected to play an active role and to contribute significantly in the development and utilization of ICT in banking transactions.

The maximum and minimum value of IKLH is 64.50 and 60.25 points with an average value of 62.60 point. IKLH scale between 0 - 100 points with the meaning of approaching 100 point is superior (Ministry of Environment and Forestry RI, 2014). The existing IKLH scores in Indonesia indicate that the quality of the environment tends to be less. This condition can be utilized by Islamic banks in Indonesia to play a more active role in encouraging all of its customers in reducing environmental impacts. In addition, Islamic banking can also provide environmental impact reduction initiatives in business activities and organizations.

Table 1. Description of Islamic banking Assets and Financing Growth, Value of IDI and IKLH in 2010-2016

\begin{tabular}{lccccccc}
\hline \multicolumn{1}{c}{ Item } & GABUS & GABPRS & GABS & GFBUST & GFBPRST & IDI & IKLH \\
\hline Mean & 33.69 & 26.55 & 33.48 & 34.27 & 26.49 & 3.41 & 62.60 \\
Median & 34.06 & 28.54 & 34.05 & 43.69 & 29.84 & 3.43 & 63.20 \\
Maximum & 49.17 & 33.48 & 48.60 & 50.56 & 32.80 & 3.83 & 64.50 \\
Minimum & 13.45 & 17.74 & 13.56 & 6.86 & 15.19 & 3.01 & 60.25 \\
\hline
\end{tabular}

Source: OJK; KLHK; And ITU (processed)

Description: GABUS = growth of assets of Islamic commercial bank and Islamic business unit; GABPRS = asset growth of Islamic rural bank; GABS = growth of Islamic banking (Islamic commercial bank, Islamic business unit, and Islamic rural bank) assets; GFBUST = growth of financing in sectoral economy of Islamic commercial bank and Islamic business unit; GFBPRST = growth of financing in sectoral economy of Islamic rural bank; IDI = ICT Development Index of Indonesia; IKLH = Environmental Quality Index of Indonesia. 
Avalaible online at http://journals.ums.ac.id, Permalink/DOI: 10.23917/jep.v20i2.6757

Jurnal Ekonomi Pembangunan: Kajian Masalah Ekonomi dan Pembangunan, 20 (2), 2019, 176-192

Table 2. Description of Financing Growth by Sectoral Economy of Islamic Banking in Indonesia during 2010-2016 (\%)

\begin{tabular}{|c|c|c|c|c|c|c|c|c|c|c|}
\hline Item & GFBUS1 & GFBUS2 & GFBUS3 & GFBUS4 & GFBUS5 & GFBUS6 & GFBUS7 & GFBUS8 & GFBUS9 & GFBUS10 \\
\hline \multicolumn{11}{|c|}{ Islamic bank and Islamic Business Unit } \\
\hline Mean & 31.73 & 32.06 & 40.18 & 53.43 & 18.00 & 27.77 & 9.05 & 28.89 & 38.09 & 44.76 \\
\hline Median & 27.62 & 33.67 & 35.21 & 47.62 & 19.28 & 28.51 & 10.36 & 28.12 & 50.05 & 51.33 \\
\hline Maximum & 61.08 & 54.73 & 74.45 & 93.98 & 39.68 & 52.18 & 28.26 & 48.08 & 76.48 & 88.47 \\
\hline \multirow[t]{2}{*}{ Minimum } & 12.67 & 6.97 & 20.38 & 17.02 & -4.08 & 13.39 & -9.18 & -3.37 & -1.27 & -1.21 \\
\hline & GFBPRS1 & GFBPRS2 & GFBPRS3 & GFBPRS4 & GFBPRS5 & GFBPRS6 & GFBPRS7 & GFBPRS8 & GFBPRS9 & GFBPRS10 \\
\hline \multicolumn{11}{|c|}{ Islamic Rural Bank } \\
\hline Mean & 56.53 & 79.34 & 14.42 & 53.59 & 36.23 & 27.38 & 37.88 & 19.14 & 107.08 & 20.74 \\
\hline Median & 56.79 & 38.83 & 20.64 & 48.72 & 38.01 & 21.45 & 25.91 & 15.13 & 61.47 & 18.93 \\
\hline Maximum & 109.08 & 217.21 & 37.13 & 81.08 & 43.16 & 61.18 & 84.69 & 56.65 & 246.10 & 34.66 \\
\hline Minimum & 9.29 & -23.53 & -7.30 & 15.64 & 25.57 & 7.68 & 4.93 & -7.79 & 20.03 & 2.20 \\
\hline
\end{tabular}

Sources: OJK; KLHK; and ITU (processed)

Description: 1 = Agriculture, forestry and agricultural facilities; $2=$ Mining; $3=$ Manufacturing; $4=$ Water, gas and electricity; $5=$ Construction; $6=$ Trade, restaurants and hotels; $7=$ Transport, cargo storage and communication; 8 = Business Services; 9 = Social Services; $10=$ Others.

Table 2 describes the growth of Islamic banking financing by economic sector in 20102016. Based on this table, it can be seen that the financing of Islamic commercial banks and Islamic business units (GFBUS) with the highest and lowest average growth of financing are water, gas and electricity (53.43\%) and transport, cargo storage and communication $(9.05 \%)$. Meanwhile, the highest and lowest average growth of financing of Islamic rural bank (GFBPRS) were social services (107.08\%) and manufacturing (14.42\%). This economic sectoral financing allocation can be used as a consideration of the readiness of Islamic banking in the implementation of green banking.

Islamic banking has contributed to the all sectoral economy in Indonesia. The Islamic commercial banking tends to support two sectors, namely: (a) water, gas and electricity; and (b) others. These sectors are large scale of business and tend to give positive return to the bank. Furthermore, the Islamic commercial banking can support industries such as manufacturing, and agriculture, maritime \& forestry. I argue that those sectors can give a positive return to the bank because the Government of Indonesia has concerned to promote it. This arguments also refers to the financing allocation from Islamic rural banking tends to high for those sectors.

Table 3 shows the correlation of Islamic banking asset, Islamic banking financing, IDI and IKLH. Based on Table 3 it can be seen that the correlation between Islamic banking asset (GABS) and Islamic banking financing (GFBUST and GFBPRST) is positive and strong. The correlation values between GABS with GFBUST and GFBPRST are 0.97 and 0.87, respectively. This is a positive signal in the development and acceleration of Islamic banking. However, these results should also be linked to the development of ICT and environmental quality in Indonesia.

The correlation between asset and financing of Islamic banking with IDI and IKLH is negative. There are five correlation results that can be explained regarding banking indicators, IDI and IKLH. The first correlation is GABUS correlates negatively and strongly with IDI and IKLH. The second correlation is GABPRS 
correlates negatively and moderately with IDI and IKLH. The third correlation is GABS correlates negatively and strongly with IDI and IKLH. The fourth correlation is GFBUST correlates negatively and strongly with IDI and IKLH. Finally, the GFBPRST correlates negatively and moderately with IDI and IKLH.

The correlation results indicate that the development of Islamic banking has not been able to encourage the development and utilization of ICT properly and maximally. This condition needs to be a consideration of Islamic banking in the implementation of digital branch established by OJK.

The correlation between asset and financing of Islamic banking with IKLH is also negative. This indicates that Islamic banking can not play an active role in controlling the environmental impact of the allocated financing. Islamic banking awareness in maintaining the environmental quality is expected to improve the environmental quality and financial transactions simultaneously. The correlation result of Islamic banking financing based on sectoral economy can be seen in appendix.

Based on the correlation of financing of Islamic commercial bank and Islamic business unit by economic sectors there are some economic sectors that have negative and strong correlation with IDI and IKLH (see appendix). These sectors are Manufacturing; Water, gas and electricity; Construction; Trade, restaurants and hotels; and Others. And then, The allocation of financing to these sectors contributes to the reduction of environmental quality. In addition, financing in these sectors is also unable to encourage faster ICT development. Thus, Islamic commercial bank and Islamic business unit need to improve the supervision and assistance of environmental impacts caused by business activities in these sectors.

Meanwhile, correlation of Islamic rural bank (BPRS) financing by economic sector there are some economic sectors that have negative and strong correlation with IDI and IKLH (see appendix). These sectors cover Agriculture, forestry and agricultural facilities; and Trade, restaurants and hotels. Both sectors can encourage environmental quality degradation and have not been able to encourage the development of ICT development in Indonesia. Therefore, BPRS managers need to improve supervision and assistance in both sectors in order to control environmental impacts.

BPRS financing in the Others Sector is positively and moderately correlated with IDI but positively and strongly correlated with IKLH. These sectors tend to be able to encourage improved environmental quality and develop ICT. However, these sectors need to be identified in more detail about their activities whether they are dominant to business or nonprofit activities. This is used to identify the multiplier impacts that can be generated when BPRS financing is upgraded for the sector. The impact of the multiplier is not only aimed for utilizing ICT in banking transactions but also for controlling of environmental impact on the financing of BPRS.

Table 3. Correlation Results of Islamic Banking Asset, Islamic Banking Financing, IDI and IKLH

\begin{tabular}{lccccccc}
\hline \multicolumn{1}{c}{ Variables } & GABUS & GABPRS & GABS & GFBUST & GFBPRST & IDI & IKLH \\
\hline GABUS & 1.00 & 0.83 & 1.00 & 0.97 & 0.87 & -0.85 & -0.83 \\
GABPRS & 0.83 & 1.00 & 0.83 & 0.92 & 0.98 & -0.62 & -0.48 \\
GABS & 1.00 & 0.83 & 1.00 & 0.97 & 0.87 & -0.85 & -0.83 \\
GFBUST & 0.97 & 0.92 & 0.97 & 1.00 & 0.95 & -0.78 & -0.74 \\
GFBPRST & 0.87 & 0.98 & 0.87 & 0.95 & 1.00 & -0.68 & -0.61 \\
IDI & -0.85 & -0.62 & -0.85 & -0.78 & -0.68 & 1.00 & 0.83 \\
IKLH & -0.83 & -0.48 & -0.83 & -0.74 & -0.61 & 0.83 & 1.00 \\
\hline
\end{tabular}

Sources: OJK; KLHK; and ITU (processed) 
Jurnal Ekonomi Pembangunan: Kajian Masalah Ekonomi dan Pembangunan, 20 (2), 2019, 176-192

Table 4. Result of Granger Causality Test on Asset and Financing of Islamic banking, IDI and IKLH

\begin{tabular}{lccc}
\hline \multicolumn{1}{c}{ Null Hypothesis } & Obs & F-Statistic & Prob. \\
\hline GFBUST does not Granger Cause GABS & 6 & 2.2616 & 0.2297 \\
GABS does not Granger Cause GFBUST & & 8.8768 & 0.0586 \\
GFBPRST does not Granger Cause GABS & 6 & 1.0884 & 0.3735 \\
GABS does not Granger Cause GFBPRST & & 9.2718 & 0.0556 \\
IDI does not Granger Cause GABS & 6 & 8.2539 & 0.0639 \\
GABS does not Granger Cause IDI & & 0.0998 & 0.7728 \\
IKLH does not Granger Cause GABS & 6 & 0.0147 & 0.9113 \\
GABS does not Granger Cause IKLH & & 1.1564 & 0.3610 \\
GFBPRST does not Granger Cause GFBUST & 6 & 1.5386 & 0.3030 \\
GFBUST does not Granger Cause GFBPRST & & 14.1141 & 0.0330 \\
IDI does not Granger Cause GFBUST & 6 & 22.7798 & 0.0175 \\
GFBUST does not Granger Cause IDI & & 0.0106 & 0.9244 \\
IKLH does not Granger Cause GFBUST & 6 & 1.2144 & 0.3509 \\
GFBUST does not Granger Cause IKLH & & 0.6600 & 0.4760 \\
IDI does not Granger Cause GFBPRST & 6 & 25.2688 & 0.0152 \\
GFBPRST does not Granger Cause IDI & & 0.0545 & 0.8304 \\
IKLH does not Granger Cause GFBPRST & 6 & 3.2049 & 0.1713 \\
GFBPRST does not Granger Cause IKLH & & 0.9062 & 0.4114 \\
IKLH does not Granger Cause IDI & \multirow{2}{*}{6} & 2.5789 & 0.2066 \\
IDI does not Granger Cause IKLH & 0.8291 & 0.4297 \\
\hline
\end{tabular}

Sources: OJK; KLHK; and ITU (processed)

Table 4 describes Granger Causality test results between asset and financing of Islamic banking with IDI and IKLH. Based on the table it can be seen that GABS has one-way causal with GFBUST. And then, there are six causality results between research variables. The first result is GABS has one-way causal with GFBPRST. The second result is IDI has one-way causal with GABS. The third result is GFBUST has one-way causal with GFBPRST. The fourth result is IDI has one-way causal with GFBUST. The fifth result is IDI has oneway causal with GFBPRST. Finally, the IKLH no causal with GABS, GFBUST, and GFBPRST.

GABS is a booster of financing allocation in Islamic bank and Islamic business unit (GFBUST). GABS also encourages the allocation of Islamic rural bank financing (GFBPRST). Both of these results indicate that the ability of
Islamic banking in managing assets is balanced with the ability to allocate and manage financing. In order to implement the digital and green banking those conditions are an important prerequisite to be met. Islamic bank managers in Indonesia are also encouraged to innovate products and services that can increase ICT utilization and control environmental impacts on assets and financing.

GFBUST has a causal with GFBPRST. This indicates that the financing activities of Islamic commercial bank and Islamic business unit are possible in cooperation with the Islamic rural bank. This condition indicates that there is a business linkage between Islamic banks in financing. This business linkage is expected to be improved especially in order to build ICT and to control environmental impacts on realized financing. The ability of Islamic banks 
Jurnal Ekonomi Pembangunan: Kajian Masalah Ekonomi dan Pembangunan, 20 (2), 2019, 176-192

to allocate financing that has impact on ICT development and environmental control will accelerate the implementation of digital and green banking of Islamic banking in Indonesia.

IDI encourages the development of Islamic banking assets. This condition indicates that ICT plays an important role in the management of Islamic banking assets. In addition, Islamic banking has sought towards digital facilities. Optimizing the utilization of ICT in financial transactions in Islamic banking is expected to accelerate the expansion of Islamic banking market, increasing loyal customers, and improving the quality management of banking industry. This also means that a competitive Islamic banking orientation can be realized.

IDI encourages the development of Islamic banking financing. This explains that the process of financing allocation by Islamic banks has utilized ICT. The same condition is that IDI encourages the development of Islamic rural bank financing. Thus, Islamic banking has directed its financing activities with ICT facilities. Financing transactions that are able to optimize the utilization of ICT are expected to place Islamic banking in Indonesia as an efficient banking and the leader of Islamic financial institutions in the international financial market. The ease of access to financing but still emphasizes the risk management of financing is also expected to expand the market and loyal customers.

The general conclusion from the correlation result that asset and financing of Islamic banking is negatively correlated with IDI and IKLH. Meanwhile, the result of causality indicates that IDI has relationship with asset and financing of Islamic banking. On the other hand, asset and Islamic banking financing have no causal with IKLH. This means that Islamic banking has started to utilize ICT but has not played an active role in controlling environmental impacts.
Based on the findings in this subsection, it can be analyzed readiness of Islamic banking in Indonesia in order to implement digital and green banking. Readiness is intended to find out whether Islamic banking can move the approach from the minimum digital and green business to the maximum digital and green business. In addition, readiness analysis results can also be useful in the implementation of digital branch guidelines that have been set by OJK.

Table 5 describes the assessment results of Islamic banking readiness in digital and green banking implementation in Indonesia. Based on the table it can be seen that the readiness level of digital banking in Indonesian Islamic banking is level 3. At this level Islamic banking has conducted utilization of ICT in financial transactions and has tried to lead the implementation of digital branch according to the guidance of OJK. In addition, OJK has socialized and received feedback from stakeholders related to digital branch policy.

Meanwhile, the readiness level of green banking in Islamic banking is level 1. At this level, OJK starts research on green banking and socializes to stakeholders in a limited way. In addition, Islamic banking is also just beginning to identify its ability in order to implement green banking in financial transactions both on the funding and financing.

The assessment of readiness level of Islamic banking is expected to be one of the considerations for OJK, DSN-MUI and Islamic bank actors to establish direction in realizing digital and green banking. The maximum effort of Islamic banking in implementing digital and green banking is the increased level of readiness. Thus, the embodiment of Islamic compliant banking law, competitive, and reliable will be easily achieved. In addition, Islamic banking could make Indonesia as a center for the development and application of Islamic digital and green banking at the international level. 
Jurnal Ekonomi Pembangunan: Kajian Masalah Ekonomi dan Pembangunan, 20 (2), 2019, 176-192

Table 5. Result of Readiness Level of Islamic Banking in Digital and Green Banking Implementation in Indonesia

\begin{tabular}{|c|c|c|}
\hline No. & Readiness Level of Digital Banking & Readiness Level of Green Banking \\
\hline 1 & $\begin{array}{l}\text { Correlation results indicate that assets and } \\
\text { financing of Islamic banks have not been able } \\
\text { to encourage the development of ICT. However, } \\
\text { Islamic banking is already utilizing ICT facilities } \\
\text { in its financial transactions. In addition, OJK } \\
\text { has also set guidelines for the implementation of } \\
\text { digital branch. }\end{array}$ & $\begin{array}{l}\text { The results of the correlation show that the } \\
\text { financing of Islamic commercial bank and Islamic } \\
\text { business unit encourage the environmental } \\
\text { quality degradation. The same is true of BPRS } \\
\text { financing but there is one sector of the economy } \\
\text { that tends to maintain the environmental quality } \\
\text { of the financing (Other sector). }\end{array}$ \\
\hline 2 & $\begin{array}{l}\text { The result of Granger causality indicates that } \\
\text { ICT has a causal with asset and financing of } \\
\text { Islamic banking. This finding is relevant to the } \\
\text { correlation result. In addition, this causal also } \\
\text { shows that Islamic banking has an opportunity in } \\
\text { order to improve the utilization and development } \\
\text { of ICT in financial transactions to digital branch } \\
\text { / banking. }\end{array}$ & $\begin{array}{l}\text { There is no causal between asset and financing } \\
\text { of Islamic banking with IKLH. }\end{array}$ \\
\hline 3 & Readiness Level: 3 & Readiness Level:1 \\
\hline 4 & $\begin{array}{l}\text { Readiness indicator: } \\
\text { (1) OJK and/or Islamic banking trials digital } \\
\text { branch/banking and green banking; (2) OJK gets } \\
\text { feedback and evaluates point (1); (3) OJK has } \\
\text { conducted socialization and feedback from all } \\
\text { stakeholders; and (4) there is high correlation/ } \\
\text { causal between Islamic banking indicators, ICT } \\
\text { index and Environmental quality index. }\end{array}$ & $\begin{array}{l}\text { Readiness indicator: } \\
\text { (1) OJK and/or Islamic banking has conducted } \\
\text { research and policy on digital branch/banking } \\
\text { and green banking; (2) DSN-MUI stipulates a } \\
\text { digital branch/banking and green banking fatwa; } \\
\text { (3) OJK and/or Islamic banking has conducted } \\
\text { socialization on digital branch/banking and green } \\
\text { banking to limited stakeholders; and (4) there is } \\
\text { no correlation/causal between Islamic banking } \\
\text { indicators, ICT index and Environmental quality } \\
\text { index. }\end{array}$ \\
\hline
\end{tabular}

Sources: Analysis results

There are some important points of readiness level of Islamic banking in the implementation of digital and green banking. The first point is the benchmark of digital and green banking implementation. The readiness position of Islamic banking in the implementation of digital and green banking can be a reference and evaluation to what extent they are able to achieve it. It can also be an input for Islamic banking to determine the acceleration strategy of digital and green banking achievement. Acceleration can be done with the approach of Islamic interbank business linkage in Indonesia. Sharing of ICT utilization and supervision capability over financing that negatively impact the quality of the environment can be more easily done. In addition, sharing in organizational management that leads to green banking can also be realized.

The second point is an effort to create an efficient, reliable and competitive Islamic banking. The readiness position of Islamic banking also leads them to create an efficient, reliable and competitive Islamic financial business. Increased utilization of ICT is expected to be more easily achieved business efficiency. In addition, the increasing ability of ICT development and environmental impact control is expected to place the Islamic banking as a reliable and competitive financial institution at national, regional and international level.

The third point is an effort to prepare the index of digital and green banking of Islamic banking. The readiness position of Islamic banking can also encourage OJK to develop the digital and green banking index of Islamic. This 
Jurnal Ekonomi Pembangunan: Kajian Masalah Ekonomi dan Pembangunan, 20 (2), 2019, 176-192

index is important for OJK and Islamic banking to evaluate and to improve the achievement of digital and green banking that has been achieved. In addition, OJK has instrument in assisting the increase of digital and green banking achievement in Islamic banking.

The fourth point is an effort to realize the international center of digital and green banking of Islamic banking. The readiness position of Islamic banking is also a barometer of their ability to realize Indonesia as the center of digital and green banking Islamic in the world. This effort will encourage acceleration of control of Islamic financial market especially in domestic market. Indirectly this action is also expected to shift conventional banking customers' confidence to switch to Islamic banking.

The assessment of readiness level of application of digital and green banking by Islamic banking in Indonesia has advantage and weakness. The advantage lies in the result of linkage between asset and Islamic banking financing with IDI and IKLH. In addition, OJK has also set digital branch guidelines in Indonesia. Meanwhile, the weakness of readiness level assessment is that there is no cross check data mechanism, clarification and feedback on this assessment from Islamic bank actors. This weakness can be complemented by further research by combining primary and secondary data.

\subsection{Discussion}

Readiness level of digital banking of Islamic banking in Indonesia is level 3. This indicates that efforts to utilize ICT in financial transactions to digital branch / banking already exist. Islamic banking can improve the utilization of ICT in two ways. First, Islamic banking can share ICT resources both with Islamic banks and conventional banks. Secondly, Islamic banking can increase the activity of Islamic interbank business linkage especially related to product innovation and ICT-based transaction service.
Rozzani \& Rahman (2013) find that Islamic bank in Malaysia can maintain asset efficiently. Meanwhile Sukmana \& Febriyati (2016: 89) conclude the financial performance of Islamic banking and conventional banking in Indonesia, that:

The management of conventional banks is more efficient compared to that of Islamic banks. One of the reasonsis probably due to the technology that they adopt. The advanced technology used by conventional banks may reduce their costs. Conversely, the lack of technology utilized by Islamic banks may have resulted in higher cost, such as transferring of funds from Islamic banks to other banks is still less efficient than the conventional banks.

According to Vater et al., (2012) that the effort to create digital customers can be done through integrated distribution channels; redesigning the business network; upgrading services and business operations management; strengthening business branding and business partnerships/ cooperation. Meanwhile, DeLaCastro et al., (2014) identified several attributes in the application of digital banking to conventional banking (Figure $1)$.

Readiness level green banking Islamic banking is level 1. This stage shows that Islamic banking and OJK is still in the stage of determining or reviewing green banking guidelines. In addition, the implementation of financing undertaken by Islamic banks has not been able to control the negative impact on the environment. Meanwhile, based on the Masukujjaman et al., (2016) there are several indicators that can be assessed in the application of green banking. This study indicates that green banking benefits society, according to Islamic ethics and guidance, and reduces the negative impact on the environment Masukujjaman et al., (2016). This explanation can be seen in Table 6 . 


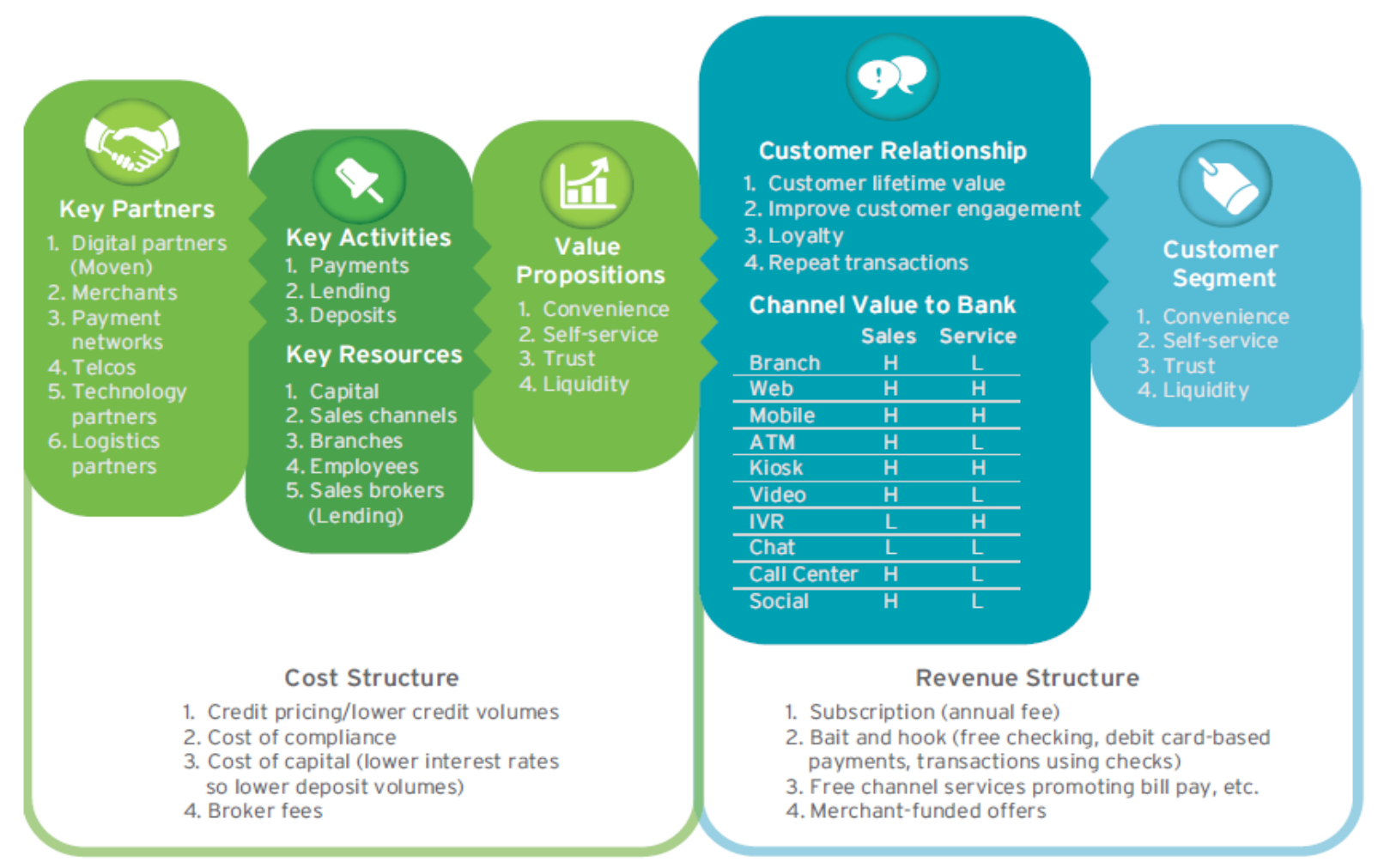

Sources: DeLaCastro et al., (2014)

Figure 1. Attributes in Implementing Digital Banking

Table 6. Banker Perception in Implementing Green Banking

\begin{tabular}{lccc}
\hline \multicolumn{1}{c}{ Representative Perception } & Disagree & Neutral & Agree \\
\hline Green banking promotes social (benefits) responsibility supported by Islam & 0 & 4 & $44(91.7 \%)$ \\
Green banking advocates cleanliness is termed as part of (Iman) faith in & 1 & $(8.3 \%)$ & 11 \\
Islam & $(2.1 \%)$ & $(22.9 \%)$ & $(75.0 \%)$ \\
Green banking reduces resource wastage is consistent with the Islamic rules & 2 & 6 & 46 \\
Green banking upholds Islamic ethics in business & $(4.2 \%)$ & $(12.5 \%)$ & $(83.3 \%)$ \\
& $(2.1 \%)$ & $(29.2 \%)$ & $(68.8 \%)$ \\
Oveall, Green banking is supported by Islamic Shariah Law & 8 & 13 & 27 \\
& $(16.7 \%)$ & $(27.1 \%)$ & $(56.2 \%)$ \\
\hline
\end{tabular}

Sources: Masukujjaman et al., (2016)

4. Conclusion, Policy Implication and 1 and 2), correlation (Table 3), and Granger Limitation causality test (Table 4). Meanwhile, the second

\subsection{Conclusion}

There are two objectives that stated in this research, namely: the relationship between Islamic banking indicators, technology and enviromental quality; and the readiness level of digital and green banking. The first objective can be explored using descriptive statistics (Table objective is figured out at Table 5 .

The description of Islamic banking indicators confirms that Islamic banking Indonesia tends to move to the positive growth. It means that the Islamic banking industry becomes struggle into financial market in Indonesia. Furthermore, the Islamic banking industry can contribute to 
utilize ICT and support quality of environment in financial transaction.

Asset and financing of Islamic banking have a negative correlation with IDI and IKLH. Asset and financing of Islamic banking also have causal with IDI but not have causal with IKLH. Islamic banking in Indonesia has utilized ICT in asset management and funding allocation/transactions. However, Islamic banking has not played an active role in the management of environmental impacts on financial transactions.

The finding of readiness level in Islamic banking industry in Indonesia covers two results. The readiness level on digital banking in Islamic banking is level 3. At this level Islamic banking has had ICT facilities in financial transactions and applied to its customers. Meanwhile, the assessment of readiness level on green banking in Islamic banking is 1. At this level OJK and Islamic banking are preparing the study and rationale implementation of green banking.

\subsection{Policy Implication}

The results of this research can be used by OJK and Islamic banking as one of consideration of application of digital branch / banking and green banking. Implementation of digital branch guidelines established by OJK (2016) should be followed by the establishment of green banking guidelines. In addition, digital branch and green banking guidelines need to get the legal legality of Islam in the form of a DSN-MUI fatwa. It is intended that the application of digital branch / banking and green banking also obey Islamic law. In order to evaluate and supervise the implementation of digital branch and green banking, OJK can determine an index of digital branch / banking and green banking in Islamic banking.

\subsection{Limitation}

This study only uses secondary data and causality method. Further research can use other methods such as VAR, DATA PANEL, AHP, Balance Score Card or other methods that can explain the TRL of Islamic banking in Indonesia in the implementation of digital and green banking. In addition, advanced research can also combine primary and secondary data.

\section{References}

Bank Indonesia (2008). Grand Strategy od Islamic Banking Market Development.

Chowdhury, M. A. A., \& Dey, M. (2016). Green Banking Practices in Bangladesh. The Cost and Management, 44(2), 34-39.

DeLaCastro, S., Erdmann, S., Krishnan, A., Kulkarni, S., \& Pande, M. (2014). Digital Banking: Enhancing Customer Experience; Generating Long-Term Loyalty. Cognizant.

Garg, S. (2015). Green Banking: An Overview. Global Journal of Advanced Research, 2(8), 1291-1296.

ITU. (2011). Measuring the Information Society. Switzerland.

Jaubert, M., Ullrich, M., Dela, R., Marcu, S., \& Malbate, J.-B. (2014). Going Digital: The Banking Transformation Road Map. Efma.

Jha, N., \& Bhome, S. (2013). A Study of Green Banking Trends in India. Internation Monthly Refereed Journal of Research in Management \& Technology, II(May), 127132.

Julia, T., Rahman, M. P., \& Kassim, S. (2016). Shariahcomplianceofgreenbankingpolicyin Bangladesh. Humanomics, 32(4), 390-404. https://doi.org/10.1108/H-02-2016-0015

Kamra, S. (2014). Digital Transformation in Banking - The Future of Banking. Happiest Minds.

Lipton, A., Shrier, D., \& Pentland, A. (2016). Digital Banking Manifesto: The End of Banks? Massachusetts Institute of Technology.

Masukujjaman, M., Siwar, C., Mahmud, R., \& Alam, S. S. (2016). Bankers' perception of Green Banking: Learning from the experience of Islamic banks in Bangladesh. 
Jurnal Ekonomi Pembangunan: Kajian Masalah Ekonomi dan Pembangunan, 20 (2), 2019, 176-192

Malaysian Journal of Society and Space, 12(2), 144-153.

Ministry of Communications and Informatics RI. (2011). Teknologi Informasi dan Komunikasi (TIK) di Sektor Bisnis Indonesia 2011.

NASA. (2017). Technology Readiness Level Definitions. Retrieved from https:// www.nasa.gov/pdf/458490main_TRL_ Definitions.pdf

Nor, S. M. (2016). Islamic Social Bank: An Adaptation of Islamic Banking? Jurnal Pengurusan, 46, $43-52$.

Otoritas Jasa Keuangan. (2015). No Title. Oadmap Perbankan Syariah Indonesia (Roadmap of Indonesian Syariah Banking). Jakarta, Indonesia.

Otoritas Jasa Keuangan. (2016). Panduan Penyelenggaraan Digital Branch. Otoritas Jasa Keuangan.

Oyegunle, A., \& Weber, O. (2015). Development of sustainability and green banking regulations existing codes and practices. Centre for International Governance Innnovation, (65). Retrieved from https://www.cigionline.org/publications/ development-sustainability-and-greenbanking-regulations-existing-codes-andpractices

Rozzani, N., \& Rahman, R.A. (2013). Determinants of Bank Performance: Conventional versus Islamic. Jurnal Pengurusan, 39, 129-139.

Sahoo, B. P., Singh, A., \& Jain, N. (2016). Green Banking in India: Problems and Prospects. International Journal of Research Granthaalayah, 4(8). https://doi. org/10.5281/zenodo.61169

Sukmana, R., \& Febriyati, N. A. (2016). Islamic Banks vs Conventional Banks in Indonesia: An Analysis on Financial Performances. Jurnal Pengurusan, 47, 81 - 90.

Taylor, R. (1990). Interpretation of the Correlation
Coefficient: A Basic Review. Journal of Diagnostic Medical Sonography, 6(35-39).

Uddin, M. N. (2016). Shari'ah Based Banking and Green Financing: Evidencefrom Bangladesh Mohammad Nazim Uddin. IOSR Journal of Business and Management, 18(1), 79-90. https://doi.org/10.9790/487X-18137990

Vater, B. D., Cho, Y., \& Sidebottom, P. (2012). The digital challenge to retail banks. Bain \& Company.

White, H., \& Pettenuzzo, D. (2014). Granger Causality, Exogeneity, Cointegration, and Economic Policy Analysis. Journal of Econometrics, 178, 316-330. 
Avalaible online at http://journals.ums.ac.id, Permalink/DOI: 10.23917/jep.v20i2.6757

Jurnal Ekonomi Pembangunan: Kajian Masalah Ekonomi dan Pembangunan, 20 (2), 2019, 176-192

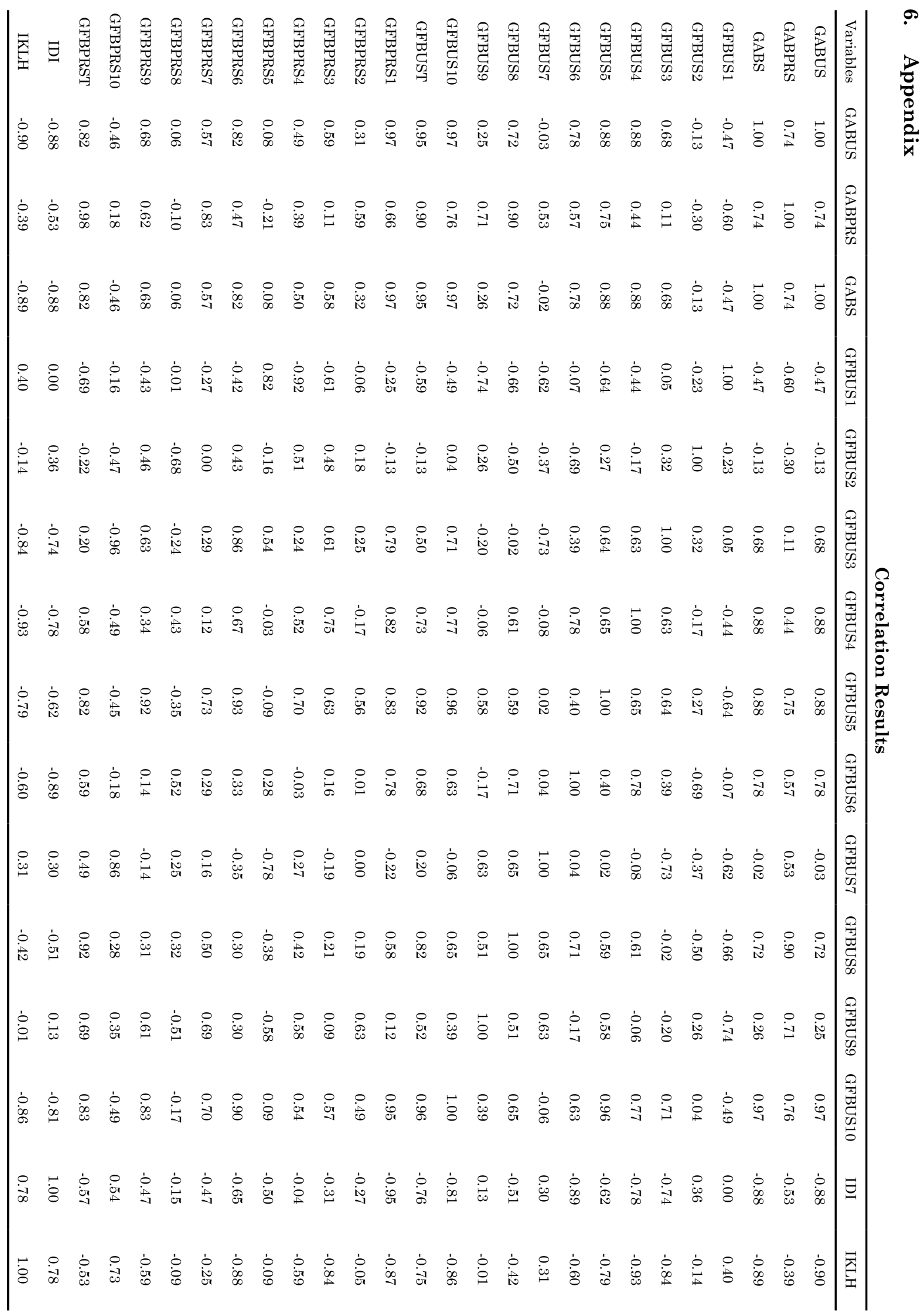

Jurnal Ekonomi Pembangunan, ISSN 1411-6081, E-ISSN 2460-9331 


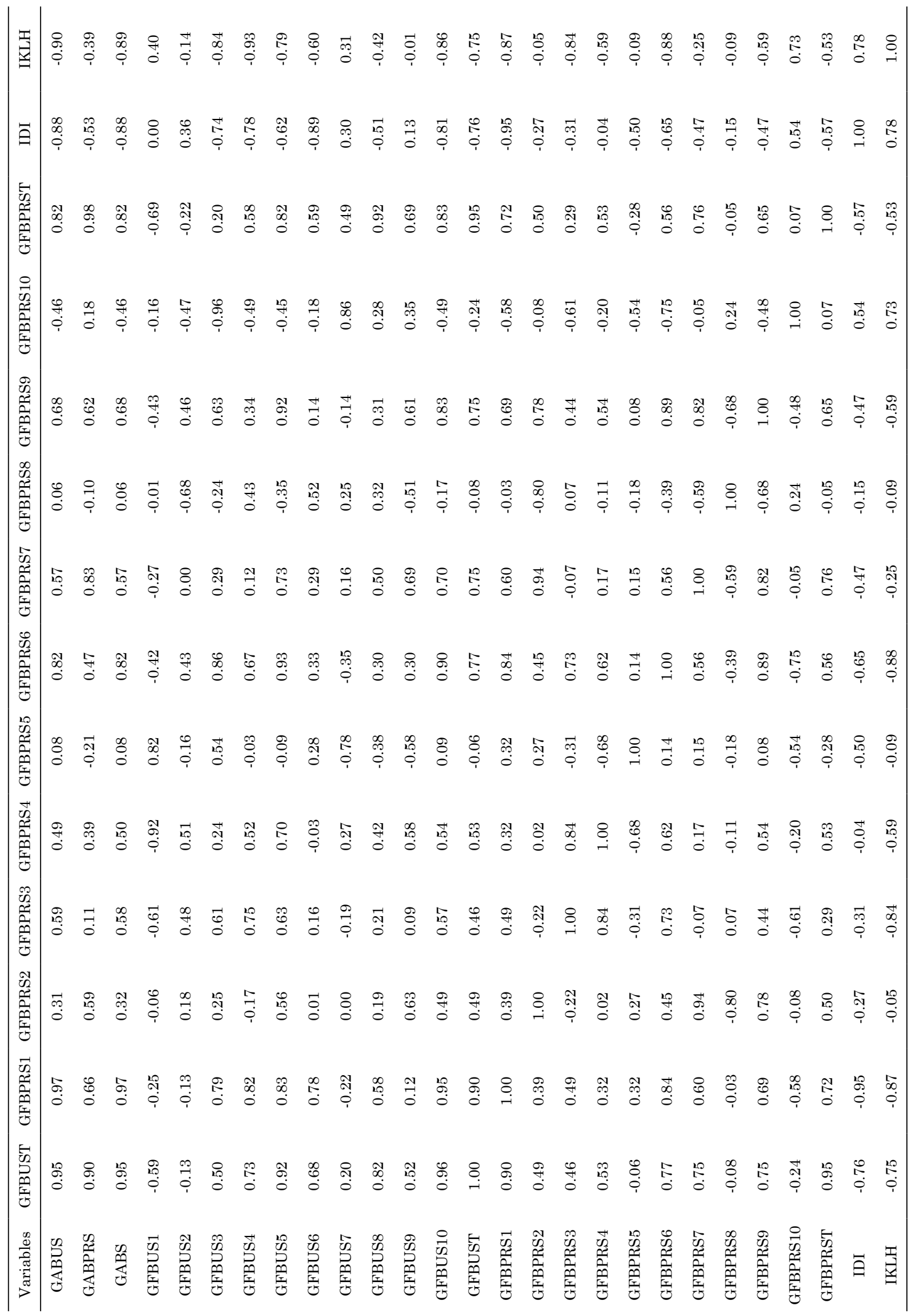


The determination of Islamic banking readiness level in the implementation of digital and green banking in Indonesia:

a. Level 1 is the basic concept of technology Level 1 is indicated by: (1) OJK and/or Islamic banking has conducted research and policy on digital branch/banking and green banking; (2) DSN-MUI stipulates a digital branch/banking and green banking fatwa; (3) OJK and/or Islamic banking has conducted socialization on digital branch/banking and green banking to limited stakeholders; and (4) there is no (negative) correlation/causal between Islamic banking indicators, ICT index and environmental quality index.

b. Level 2 is the determination of the concept and application of technology

Level 2 is indicated by: (1) OJK and/or Islamic banking establishes digital branch/ banking and green banking policy; (2) OJK designed the implementation plan of points (1); (3) OJK has socialized the digital branch/banking and green banking to the community/customers of Islamic banking; and (4) there is low correlation (positive)/ causal between Islamic banking indicators, ICT index and environmental quality index.

c. Level 3 is the empirical application of concepts

Level 3 is indicated by: (1) OJK and/ or Islamic banking trials digital branch/ banking and green banking; (2) OJK gets feedback and evaluates point (1); (3) OJK has conducted socialization and feedback from all stakeholders; and (4) there is high correlation (positive)/causal between Islamic banking indicators, ICT index and environmental quality index.

d. Level 4 is validation of technology implementation

Level 4 is indicated by: (1) OJK supervises the implementation of digital branch/ banking and green banking; (2) OJK ensures that all rules of digital branch/banking and green banking are implemented by Islamic banking; and (3) there is high correlation (positive)/causal between Islamic banking indicators, ICT index and environmental quality index.

e. Level 5 is the validation of the results of technology implementation

Level 5 is indicated by: (1) Islamic banking has implemented digital branch/banking and green banking at head office/home office; (2) OJK monitors, evaluates and supervises the points (1); and (3) there is high correlation (positive)/causal between Islamic banking indicators, ICT index and environmental quality index.

f. Level 6 is a limited and consistent technology demonstration

Level 6 is indicated by: (1) Islamic banking has implemented digital branch/banking and green banking at head office/home office; (2) OJK documents points (1) in the form of digital branch/banking and green banking report; and (3) there is high correlation (positive)/causal between Islamic banking indicators, ICT index and environmental quality index.

g. Level 7 is a consistent technology demonstration

Level 7 is indicated by: (1) Islamic banking has implemented digital branch/banking and green banking to all branch offices and cash offices; (2) OJK monitors and supervises the implementation of points (1); (3) OJK documents points (1) in the form of digital branch/banking and green banking report; and (4) there is high correlation (positive)/ causal between Islamic banking indicators, ICT index and environmental quality index.

h. Level 8 is a precise and consistent technology implementation

Level 8 is indicated by: (1) Islamic banking has implemented digital branch/banking and green banking to all owned offices; (2) OJK establishes digital branch / banking index and green banking index; (3) OJK documents points (1) in the form of digital branch/banking and green banking report; and (4) there is high correlation (positive)/ 
Avalaible online at http://journals.ums.ac.id, Permalink/DOI: 10.23917/jep.v20i2.6757

Jurnal Ekonomi Pembangunan: Kajian Masalah Ekonomi dan Pembangunan, 20 (2), 2019, 176-192

causal between Islamic banking indicators, ICT index and environmental quality index.

i. Level 9 is a technology/system has been tested and reliable

Level 9 is indicated by: (1) Islamic banking has implemented digital branch/banking and green banking to all owned offices consistently; (2) Islamic banking periodically evaluates point (1); (3) OJK publishes an index of digital branch/banking and green banking of Islamic banking; (4) OJK documents points (1) in the form of digital branch/banking and green banking report; and (5) there is high correlation (positive)/ causal between Islamic banking indicators, ICT index and environmental quality index. 